\title{
APXITEKTУPA
}

DOI: https://doi.org/10.32839/2304-5809/2021-3-91-28

уДК 699.8

Кучменко I.M., Варич Г.С., Авагян М.E.

Одеська державна академія будівництва та архітектури

\section{НОРМАТИВНА БАЗА УКРАЇНИ В ОБЛАСТІ СОНЦЕЗАХИСТУ БУДІВЕЛЬ}

\begin{abstract}
Анотація. При проектуванні будинків в південних регіонах України виникає проблема захисту приміщень від прямої сонячної радіащії, що викликає тепловий і світловий дискомфорт. Практика будівництва будівель в південних районах показує, що багато будинків проектуються без обліку надлишку теплової дії інсоляції в літній період. У будівлях зі значним доступом інсоляції в приміщення використовуються технічні засоби сонцезахисту (кондиціонування, внутрішні системи охолодження), що призводить до значних енерговитрат. Жорсткість вимог щодо економії енергії призводить до необхідності розробки нових норм $з$ проектування і застосування сонцезахисних пристроїв. Вони здатні істотно зменшити навантаження на системи охолодження будівель в період перегріву влітку та зберегти або незначно зменшити пасивне сонячне опалення взимку.
\end{abstract}

Ключові слова:інсоляція, сонцезахисні пристрої, енергоефективність будівель, нормування сонцезахисту.

Kychmenko Irina, Varych Hanna, Avagian Mariam Odessa Academy of Civil Engineering and Architecture

\section{NORMATIVE BASE OF UKRAINE IN THE AREA OF SOLAR SHADING OF BUILDINGS}

Summary. When designing houses in the southern regions of Ukraine there is a problem of protection of premises from direct solar radiation, which causes thermal and light discomfort. The practice of building construction in the southern areas shows that many houses are designed without taking into account the excess thermal action of insolation in the summer. In buildings with significant access of insolation to the premises, technical means of sun protection (air conditioning, internal cooling systems) are used, which leads to significant energy consumption. The rigidity of energy saving requirements leads to the need to develop new standards for the design and use of sun protection devices. They are able to significantly reduce the load on the cooling systems of buildings during the overheating period in summer and maintain or slightly reduce passive solar heating in winter. Due to the high brightness of sunlight and the appearance of glare on the mirror-reflecting surfaces, there is light (visual) discomfort. Sunscreens should be designed to provide protection against overheating in summer, reduce heat loss during the cold season, increase viewer comfort and visual contact with the environment. The norms set the minimum duration of insolation, but an excess of direct solar radiation can also lead to negative consequences. The practice of building construction in the southern areas shows that many houses are designed without taking into account the excess thermal action of insolation in the summer. In buildings with unlimited access of insolation to the premises, technical means of sun protection (air conditioning, internal cooling systems) are used, which leads to significant energy consumption. Currently in Ukraine there is no normative document that regulates the rules of design of sun protection devices, their types, requirements for them; basic efficiency criteria; methods of their determination. The peculiarity of the method is the use of a minimum amount of climatological information about the construction area. To perform calculations, it is enough to know: latitude, monthly average values of air temperature and its daily amplitude.

Keywords: insolation, solar devices, energy efficiency of buildings, sun protection control.

$\Pi$ остановка проблеми. Вид з вікон істотно впливає на сприйняття інтер'еру. Зберегти зоровий зв'язок із зовнішнім середовищем, але при цьому мінімізувати її негативні прояви дозволяе зовнішній сонцезахист. Було встановлено, що внутрішні системи захисту від сонця знижують нагрівання приміщення приблизно на сім градусів Цельсія, тоді як мінімальні показники зовнішньої сонцезахисту більше майже в півтора рази. Зовнішні системи відсікають світловий потік до того, як він досягне вікна. Вони виявляються ефективнішими і для боротьби з відблисками. А крім цього, можуть захищати скло під час дощу та снігопаду, і незначно зменшувати зовнішній шум.

Системи зовнішнього сонцезахисту вже настільки міцно увійшли в життя кожного европейця, що складно уявити собі новий будинок, запроектований без використання хоча б базових іiі елементів. В нашій країні це скоріше рідкість, щоб на етапі проекту ми отримували віконні про- різи, в яких передбачено використання ролет або рафштор. Хоча ще з 1 травня 2017 року ввійшов в силу державний норматив [1], в якому досить чітко позначено, що при кондиціюванні приміщення необхідно передбачати і сонцезахист.

Аналіз останніх досліджень і публікацій. Сучасні вимоги до інсоляції приміщень житлових і громадських будівель встановлюються санітарними та будівельними нормами $[1 ; 4]$. Розрахунки тривалості інсоляції е обов'язковим розділом в складі передпроектної та проектної документації [4]. Згідно з ДБН «Теплова ізоляція» [1] під час проектування необхідно передбачати сонцезахисні пристрої.

Нормами встановлюеться мінімальна тривалість інсоляції, проте надлишок прямої сонячної радіації також може призводити до негативних наслідків. Практика будівництва будівель в південних районах показуе, що багато будинків проектуються без обліку надлишку теплової дії ін- 
соляції в літній період. У будівлях з безмежним доступом інсоляції в приміщення використовуються технічні засоби сонцезахисту (кондиціонування, внутрішні системи охолодження), що призводить до значних енерговитрат.

Через велику яскравість сонячного світла і появи відблисків на дзеркально відображаючих поверхнях виникає світловий (візуальний) дискомфорт. Сліпуче світло і гнітюча спека несприятливо впливають на організм і психоемоційний стан людини.

Виділення невирішених раніше частин загальної проблеми. Недостатність нормативної бази в сфері сонцезахисту, практична відсутність державних стандартів на розробку, застосування та випробування сонцезахисні пристрої (СЗП) ускладнюе їх реальне проектування. Заходи щодо обмеження теплового дії інсоляції зводяться на практиці або до застосування жалюзі (часто внутрішніх, що неефективно), або, при великих площах скління фосадів, до використання сонцезахисних скла або плівок, що змінюють спектр природного світла в приміщенні.

Жорсткість вимог до енергозбереження, високі температури і велика інтенсивність теплової сонячної радіації в південних областях нашої країни викликають необхідність розширення застосування сонцезахисних пристроїв в будівлях різного призначення, а отже, і розробки нових нормативних документів.

Головною метою цієї роботи є аналіз існуючих нормативних джерел і вибір методики, яка дозволяе визначити оптимальний тип сонцезахисних пристроїв без складних обчислень і з використанням мінімальної необхідної інфрормації, яку можна знайти в загальнодоступних джерелах всесвітньої мережі.

Виклад основного матеріалу. Вимоги щодо обмеження сонячного тепла поширюються на приміщення житлових будинків, дитячих, середніх навчальних, лікувально-профілактичних установ, що мають південно-західну і західну оріентацію вікон. Для захисту від інсоляцї рекомендуються, насамперед, архітектурно-планувальні заходи (орієнтація і планування будівель, благоустрій територій), а при їх недостатній едективності - конструктивні і технічні засоби сонцезахисту (кондиціонування, внутрішні системи охолодження, жалюзі).

Зауважимо, що такі нормативи по сонцезахисту носять неякісний характер, так як не містять чітких рекомендащій щодо обмеження надмірної теплової дії інсоляції. Якщо вимоги до інсоляції диференційовані по зонах території України (наприклад, в зоні на південь від $48^{\circ} \mathrm{c}$. ш. тривалість безперервної інсоляції повинна становити не менше 1,5 годин на день 322 лютого по 22 жовтня), то в параграфі про сонцезахист такого поділу немає. Визначення ефективності сонцезахисних пристроїв по цих картах вимагають від проектувальників значних додаткових обчислень. Крім того, вони розроблені тільки для прямої сонячної радіації.

У складі правил «Теплова ізолящія» [1] рекомендовано передбачати сонцезахисні пристрої для світлопрозорих конструкцій, орієнтованих на південно-західний та західний сектори горизонту в межах (200-290) ${ }^{\circ}$ в залежності від відсотка скління та архітектурно-будівельного кліматичного району. Геометричні параметри яких необхідно розраховувати за допомогою комплек- сних сонячних карт, які $є$ хорошим графічним інструментом для визначення геометричних параметрів оптимізованих СЗУ, але не дозволяють кількісно визначити їх едективність.

Для обмеження річного перегріву приміщень від впливу сонячної радіації необхідно масово використовувати сонцезахисні пристрої (СЗП). Значення СЗП в даний час недооцінюеться, хоча вони здатні істотно зменшити навантаження на системи охолодження будівель в період перегріву при збереженні або незначному зменшенні пасивного сонячного опалення взимку. Крім того, проектувальники не вміють їх проектувати. Однією з причин цього е відсутність простого і наочного інструментарію, що дозволяе швидко оцінити ефрективність проектованих СЗУ.

Сонцезахисні пристрої повинні бути спроектовані таким чином, щоб забезпечити захист від перегріву влітку, знизити тепловтрати в холодний період року, підвищити глядацький комфорт і візуальний контакт із зовнішнім середовищем.

В Україні прийнятий стандарт ДСТУ Б.А.2.212.2015 «Енергетична ефрективність будівель. Метод розрахунку енергоспоживання при опаленні, охолодженні, вентилящіі, освітленні та гарячому водопостачанні. [4], який визначає методику розрахунку енергії на опалення та охолодження будинків. Одним з основних пунктів цього стандарту є методика розрахунку сонячних теплонадходжень. Джерелом теплових надходжень від сонця $є$ сонячна радіація, режим якої характерний у даній місцевості, та визначається орієнтацією сприймаючих поверхонь, постійним чи рухомим затіненням, пропусканням та поглинанням сонячної енергії й характеристиками теплопередачі сприймаючих поверхонь. Сонячні теплонадходження визначають, базуючись на еквівалентних площах інсоляції відповідних світлопрозорих елементів будівлі та на поправках до затінення сонця зовнішніми перешкодами, які виражаються понижувальним коедріцієнтом зовнішнього затінення.

Для розрахунку геометричних параметрів сонцезахисних пристроїв (СЗП) для подальшого виявлення критерію затінення використовують методи 3 використанням сонячних карт (рис. 1) та набір тіньових кутомірів-шаблонів тіньових масок для горизонтальних, вертикальних сонцезахисних пристроїв та СЗП загального положення які запровадженні в нормативну базу [4] «Настанова з розрахунку інсоляпії об'єктів цивільного призначення».

Також у достатньо доступній форомі прості i загальнодоступні методи інсоляційних розрахунків, визначення оптимальної орієнтації будівель і вибору сонцезахисних пристроїв, рішення всіх основних завдань по інсоляції, які можуть виникнути в процесі проектування, а також методика інсоляційних розрахунків для різних типів житлових і громадських будівель наведені у Штейнберга [2] «Расчет инсоляции зданий.»

Маски горизонтальних сонцезахисних пристроїв матимуть сегментну форму, маски вертикальних ребер підуть по радіальних лініях. Наклавши «тіньову маску» на діаграму руху сонця, можна визначити час, коли сонячні промені будуть затримуватися сонцезахистом. Знаючи діаграму надтеплого періоду, можна визначити потрібну «тіньову маску» і по ній знайти необхідний сонцезахисний пристрій (рис. 2). 


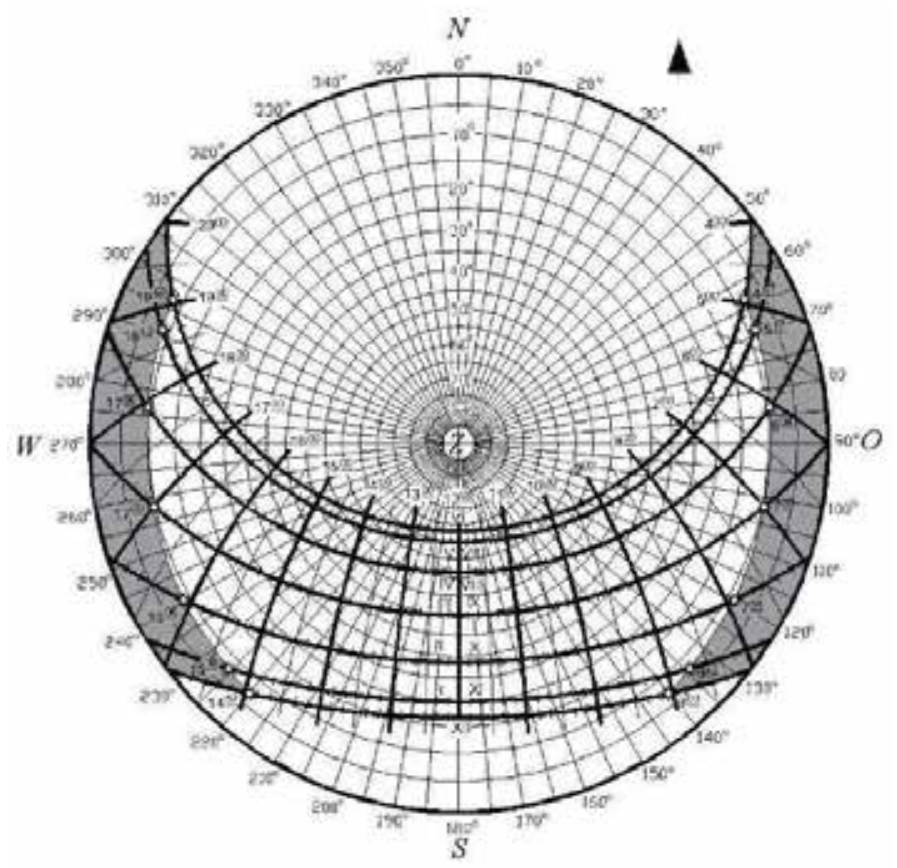

Рис. 1. Сонячна карта для м. Киева $\left(50,5^{\circ}\right.$ С.Ш.)

Перевага цього методу полягає в тому, що він враховуе температурно-кліматичні особливості досліджуваного району. Недоліком є трудомісткість розрахунку і обмеженість, так як вирішуються тільки питання сонцезахисту, а не взагалі інсоляції об'єктів.

Висновки. Особливість методики полягає в використанні мінімальної кількості кліматологічної інфрормації про район будівництва. Для виконання розрахунків достатньо знати: географрічну широту, щомісячні середні значення температури повітря та її добової амплітуди.

В даний час в Україні існуе нормативний документ «Настанова 3 розрахунку інсолящії об'єктів цивільного призначення», який регла- ментує правила проектування СЗП, їх види, вимоги, що пред'являються до них; основні критерії ефрективності; методи їх визначення [5]. Положення, що встановлюються у цій Настанові, дозволяють визначати величину розрахункової тривалості інсоляції приміщень і територій та складати розділ проектної документації, який стосуеться реалізації вимог до інсоляції СанПиН [2] 3 урахуванням впливу тривалості інсоляції на енергозбереження. Крім того, положення ціеї Настанови дають можливість визначати максимально можливі розміри нового будинку за умов непорушення інсоляційних вимог в існуючих будинках та на території забудови ще на стадії передпроектних розробок.

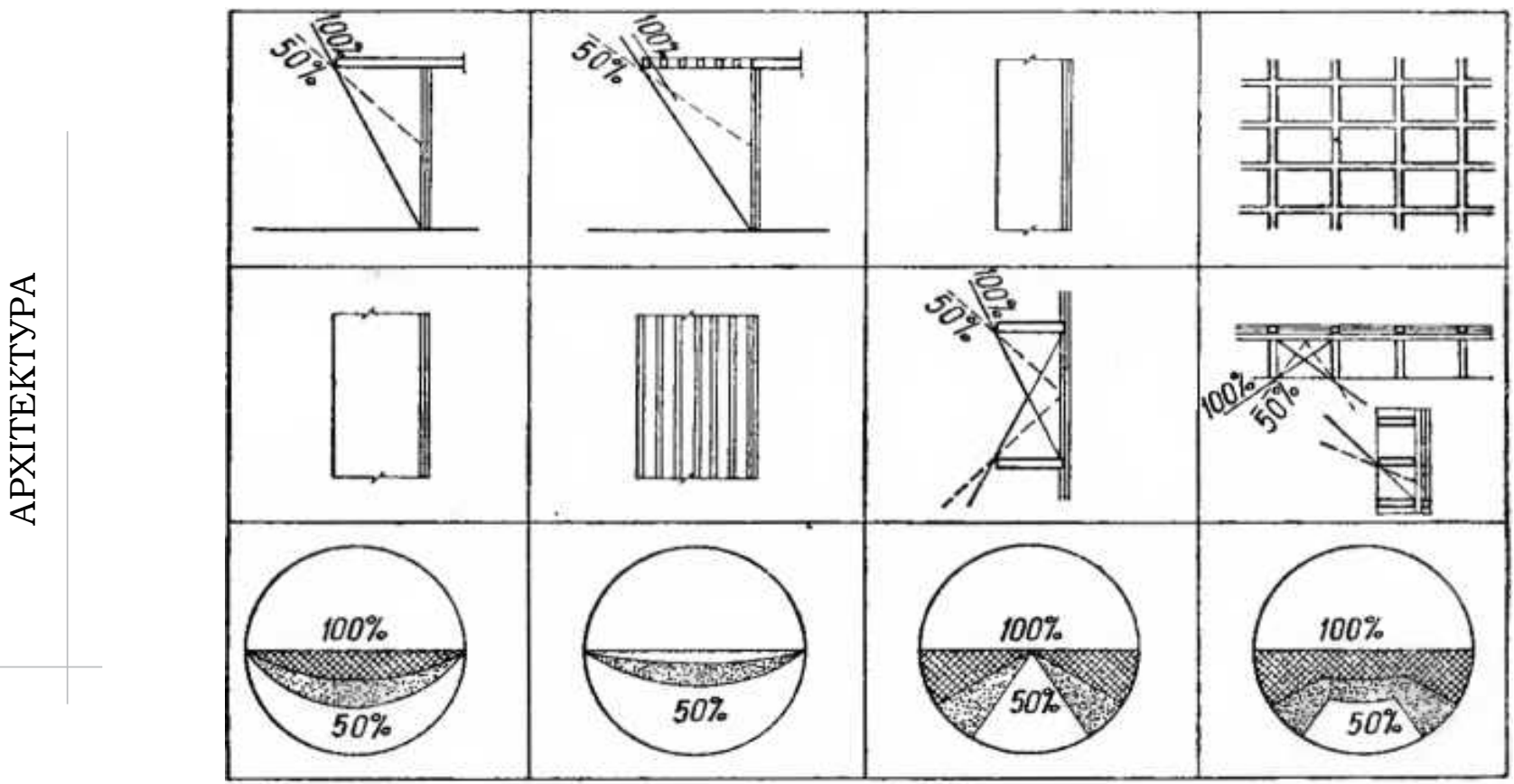

Рис. 2. Метод «тіньових масок" розрахунок різних видів сонцезахисту 


\section{Список літератури:}

1. ДБН В.2.6-31:2016. Теплова ізоляція будівель. 2016. 65 с. Державні будівельні норми України.

2. Штейнберг А.Я. Солнцезащита зданий. 1986. 84 с.

3. ДСТУ Б А.2.2-12:2015. Енергетична ефективність будівель. Метод розрахунку енергоспоживання при опаленні, охолодженні, вентиляції, освітленні і гарячому водопостачанні. 2015. 137 с. Національний стандарт України.

4. ДСТУ-Н Б В .2.2-27:2010. Настанова з розрахунку інсоляції об’ектів цивільного призначення. 2010.90 с. Національний стандарт України.

\section{References:}

1. DBN V.2.6-31:2016. Teplova izoliatsiia budivel [Thermal insulation of buildings], 2016, 65 p. Derzhavni budivelni normy Ukrainy.

2. Shteinberh A.Ia. (1986) Solntsezashchyta zdanyi [Sun protection of buildings], $84 \mathrm{p}$.

3. DSTU B A.2.2-12:2015. Enerhetychna efektyvnist budivel. Metod rozrakhunku enerhospozhyvannia pry opalenni, okholodzhenni, ventyliatsii, osvitlenni i hariachomu vodo-postachanni [Energy efficiency of buildings. Method of calculating energy consumption for heating, cooling, ventilation, lighting and hot water supply], $2015,137 \mathrm{p}$. Natsionalnyi standart Ukrainy.

4. DSTU-N B V .2.2-27:2010. Nastanova z rozrakhunku insoliatsii obiektiv tsyvilnoho pryznachennia [Guidelines for calculating the insolation of civil objects], 2010, 90 p. Natsionalnyi standart Ukrainy. 